\title{
RICERCA DEL GENOTIPO HCV \\ IN UNA POPOLAZIONE DITALASSEMICI, HCV POSITIVI, DELLA LOCRIDE.
}

Romeo R., Genoese A., Lacopo V., Larosa R., Latella P., Parasporo M., Spataro A.

Centro Trasfusionale A.S. $n^{\circ} 9$, Ospedale Civile , Locri

Introduzione. Abbiamo ritenuto utile ricercare il genotipo HCV nei pazienti affetti da $ß$-Talassemia che sono risultati positivi all' HCV-RNA.

Metodi. I 36 pazienti, affetti da morbo di Cooley, nella Locride, sono d'età compresa tra i 12 e 47 anni. Questi pazienti vengono seguiti dalla nostra Pediatria ed osservati presso il nostro Centro per la diagnostica dei virus epatitici ed HIV. Abbiamo eseguito lo screening con il test Anti-HCV EIA II Cobas Core (ROCHE);

1' HCV-RNA Qualitativo con il test Cobas Amplicor HCV (ROCHE) e 1' HCV-RNA Quantitativo con il test Cobas Amplicor HCV Monitor (ROCHE). Sui campioni risultati positivi è stato ricercato il genotipo del virus $\mathrm{C}$ con il test Versant HCV Genotype Assay Lipa (Bayer).

Risultati. Il 63\% dei Talassemici, di età compresa tre 24 e 47 anni è risultato positivo agli anticorpi anti-HCV. Di essi il $48 \%$ non presenta HCV-RNA, con controlli eseguiti dal gennaio 2002 al I quadrimestre 2005 . Il 52\% risulta positivo all' HCV-RNA quali-quantitativo e 1' $84 \%$ di esso appartiene al genotipo $1 \mathrm{~b}$, per il restante $26 \%$ al genotipo $2 \mathrm{a} / 2 \mathrm{c}$. Non abbiamo trovato correlazioni tra carica virale e genotipo.

Conclusioni. Possiamo concludere che, essendo allungata e migliorata la qualità di vita dei nostri talassemici, sarà auspicabile, dopo valutazione clinica, poterli sottoporre a trattamento antivirale. 